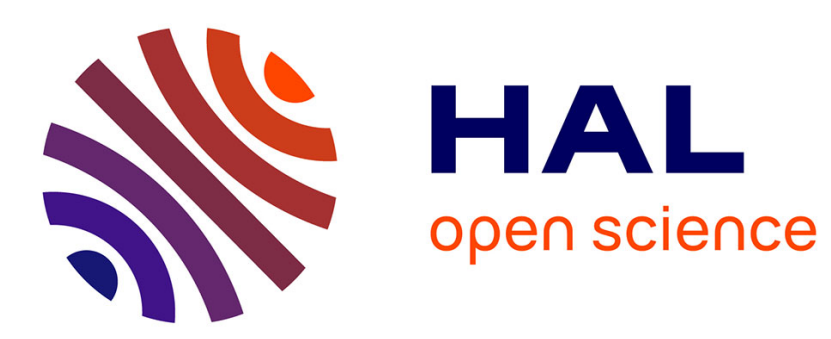

\title{
Biogeochemistry of Iron, Aluminium and Silicon in Humid Tropical Mountainous Soils (Bambouto Mountain, West Cameroon)
}

\author{
Désiré Tsozué, Dieudonné Bitom, Yves Lucas
}

\section{- To cite this version:}

Désiré Tsozué, Dieudonné Bitom, Yves Lucas. Biogeochemistry of Iron, Aluminium and Silicon in Humid Tropical Mountainous Soils (Bambouto Mountain, West Cameroon). Open Geology Journal, 2009, 3 (1), pp.70-81. 10.2174/1874262900903010070 . hal-02185619

\author{
HAL Id: hal-02185619 \\ https://hal.science/hal-02185619
}

Submitted on 16 Jul 2019

HAL is a multi-disciplinary open access archive for the deposit and dissemination of scientific research documents, whether they are published or not. The documents may come from teaching and research institutions in France or abroad, or from public or private research centers.
L'archive ouverte pluridisciplinaire HAL, est destinée au dépôt et à la diffusion de documents scientifiques de niveau recherche, publiés ou non, émanant des établissements d'enseignement et de recherche français ou étrangers, des laboratoires publics ou privés. 
See discussions, stats, and author profiles for this publication at: https://www.researchgate.net/publication/250143893

\section{Biogeochemistry of Iron, Aluminium and Silicon in Humid Tropical Mountainous Soils (Bambouto Mountain, West Cameroon)}

Article in The Open Geology Journal · September 2009

DOI: $10.2174 / 1874262900903010070$

CITATIONS

5

3 authors, including:

Désiré Tsozué

University of Maroua, Cameroon

26 PUBLICATIONS 111 CITATIONS

SEE PROFILE
READS

61

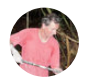

Université de Toulon

138 PUBLICATIONS 2,561 CITATIONS

SEE PROFILE

Some of the authors of this publication are also working on these related projects:

Characterization of Humic Substances extracted from the Amazon region soils View project

Pedogenesis View project 


\title{
Biogeochemistry of Iron, Aluminium and Silicon in Humid Tropical Mountainous Soils (Bambouto Mountain, West Cameroon)
}

\author{
Tsozué Désiré, Bitom Dieudonné ${ }^{*}$ and Lucas Yves
}

Department of Earth Sciences, Faculty of Science, University of Yaounde I, P.O. Box 812 Yaounde, Cameroon

\begin{abstract}
Humid tropical mountainous soils of the Bambouto volcanic mountain (West Cameroon) have been studied mainly from a chemical view point. The aim of the study was firstly to study the behaviour of iron, aluminium and silicon during pedogenesis, and to determine the forms of the three main elements. Global balance of iron is negative; it is the result of slight illuviation at the base of the profile, and moderate eluviation in the upper horizons. Selective extractions show that iron is mainly in the 'resistant' form, more moderately in the crystallized forms, while the amorphous forms are negligible, with a quasi-absence of organic amorphous forms. Silicon is highly evacuated in all horizons. Aluminium, characterized by high accumulation at the base of the profile and moderate evacuation in the upper part, presents an excess global balance. Otherwise, contrary to iron, organic amorphous forms of aluminium are well represented in these soils, which the occurrence of aluminium permits to assimilate to Aluandosols. Humid tropical mountainous soils show pedological evolution mainly dominated by the behaviour of silicon and aluminium, with iron appearing to have a negligible role. However, contrary to the temperate soils, in which bisiallitisation is the predominant process, in mountainous soils, characterized by high evacuation of silica concomitantly to notable accumulations of aluminium, allitisation predominates. This is associated with moderate andosolisation, due to the presence of a volcanic parent rock.
\end{abstract}

Keywords: Humid tropical mountainous soils, Cameroon, Bambouto Mountain, biogeochemistry, silicon, aluminium, iron, pedoclimatic parameter.

\section{INTRODUCTION}

Because of their specific environmental conditions, mountainous massifs constitute particular intertropical ecosystems. Generally domains of active volcanic activities, the main geological formations are represented by volcanic rocks. This is the case in the Andes cordillera in South America [1], in New Hebrides in the Pacific Ocean [2, 3] and Kilimandjaro Mountain [4], Cameroon Mountain [5], Manengouba Mountain [6] and Bambouto Mountain [6-8] in Africa. Due to their high altitude and because of the geothermal gradient effect [9], vegetation and the prevalent climate are generally characteristic of temperate zones $[10$, 11]. The soils which are developed in these mountainous volcanic landscapes are essentially andosolic [12-17].

Many studies have investigated the andosolic soils of tropical mountainous massifs, particularly based on their typology and cartography $[14,16]$, mineralogy, geochemistry and biogeochemistry $[12,14,15,17,18]$. They are thus relatively well known now to consist of three major elements, silicon, aluminium and iron $[14,17]$. They are also constituted of mixtures of crystalline minerals such as gibbsite, kaolinite, hematite, goethite, and of paracrystalline to amorphous minerals, such as halloysite, allophane, ferrihydrite and opale $[14,17]$. However, the pedological behaviour of the three main constitutive elements $(\mathrm{Si}, \mathrm{Al}$ and $\mathrm{Fe}$ ) remains relatively unknown, as well as the various forms (free, combined, amorphous or crystallized) in which they are all along the profiles.

*Address correspondence to this author at the Department of Earth Sciences, Faculty of Science, University of Yaounde I, P.O. Box 812 Yaounde, Cameroon; Tel: (237)99321455; E-mail: bitomoyono@yahoo.fr
The aim of this study is to determine, the behaviour of each of the three major elements $(\mathrm{Si}, \mathrm{Al}$ and $\mathrm{Fe})$ and to identify and quantify the main forms in which those three elements exist in the horizons of these mountainous soils. Moreover, because of their influence on the behaviour and on the forms of those elements in soils, pedoclimatic parameters ( $\mathrm{pH}$ and Eh) will also be characterized.

\section{ENVIRONMENTAL SETTING}

The study is located in the upper zone of Bambouto Mountain, > $2000 \mathrm{~m}$ altitude, in Western Cameroon (Fig. 1). The climate, which is pseudotropical with temperate characteristics due to altitude [11], is fresh and humid, characterized by frequent mists and fogs which impede visibility. Temperatures vary from $10-12^{\circ} \mathrm{C}$ and mean annual rainfall is $2507 \mathrm{~mm}$. Relief is uneven and natural vegetation is a lawn consisting of Sporobolus prairies typical of temperate environments. The rock is a Miocene alkaline trachyte [6], which consists mainly of sanidine. In this study zone, soils are mainly of andosolic nature [16].

\section{MATERIALS AND METHODS}

\subsection{Materials}

The studied site is an asymmetrical hill $\left(10^{\circ} 04^{\prime} 16^{\prime \prime}-\right.$ $10^{\circ} 05^{\prime} 49^{\prime \prime} \mathrm{E} ; 5^{\circ} 36^{\prime} 43^{\prime \prime}-5^{\circ} 38^{\prime} 31^{\prime \prime} \mathrm{N}$ ) with more or less spread summit and steep slopes of unequal lengths. A soil profile located at the summit part of the site has been studied; it is $2 \mathrm{~m}$ thick, with three main horizons, from bottom to top (Fig. 2):

75-200 cm: saprolitic horizon constituted by yellow brown (10YR6/8) and whitish grey (7.5YR7/0) domains, porous, loamy and massive, with the 


\section{$\stackrel{N}{N}$}

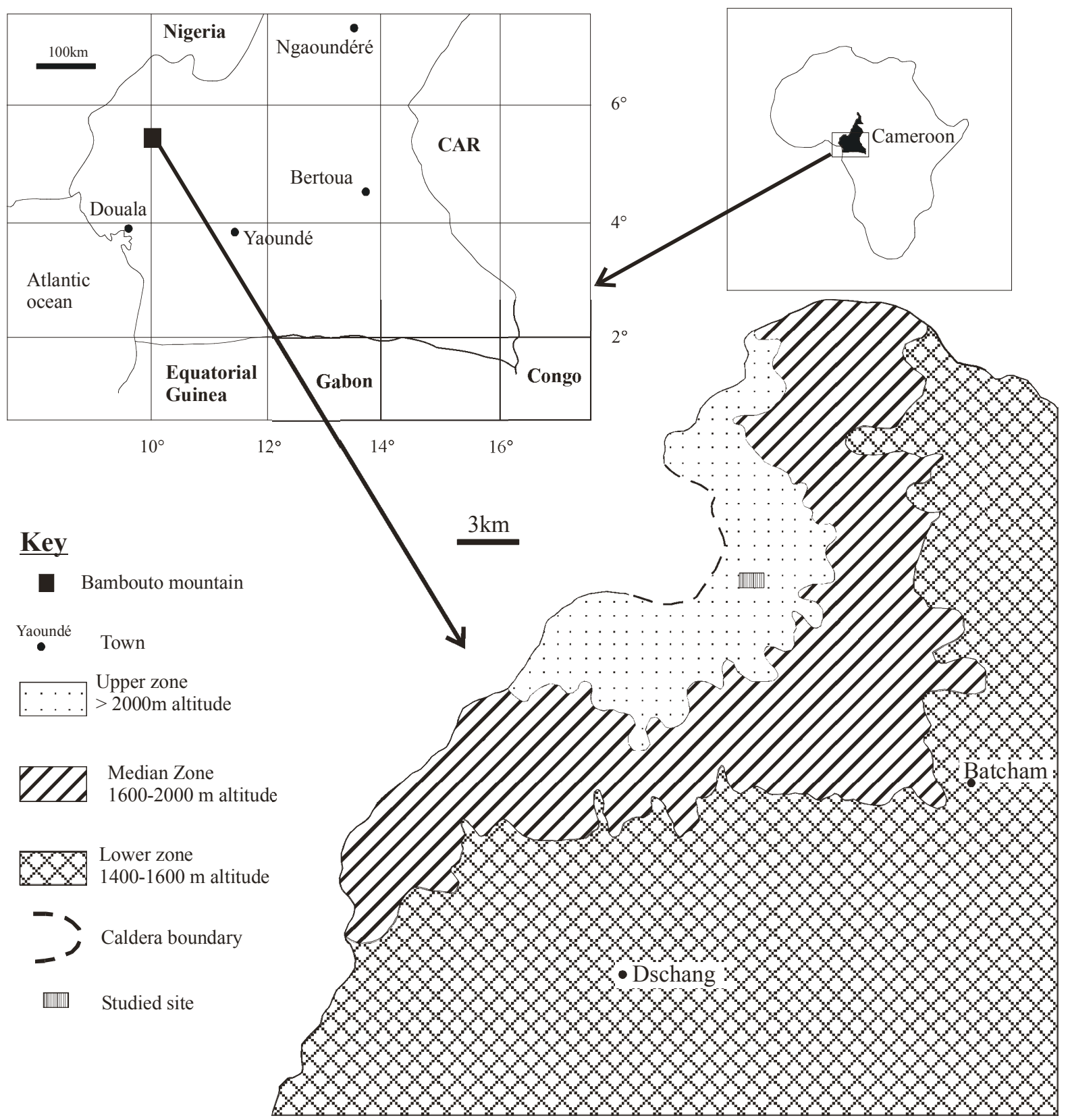

Fig. (1). Location of the studied site in the Bambouto mountain (Western Cameroon).

saccharoïdal aspect of the parent rock still preserved. In addition, many blocks of trachyte with rough surfaces are observed in this horizon. Gibbsite is the predominant mineral, associated with allophanes, halloysite, quartz and magnetite, plus goethite and rutile in the yellow brown domains, or small amounts of ferrihydrite, sanidine and ilmenite in the whitish grey ones (Table 1). Geochemically, the main constituents are $\mathrm{Al}(41.10-39.10 \%$ $\left.\mathrm{Al}_{2} \mathrm{O}_{3}\right)$, Si (23.50-22.70\% $\mathrm{SiO}_{2}$ ) and $\mathrm{Fe}(8.94-$ $6.63 \% \mathrm{Fe}_{2} \mathrm{O}_{3}$ ) (Table 2). Bases are almost absent. Small amounts of Ti $(0.44-0.73 \%$ $\left.\mathrm{TiO}_{2}\right)$, Mn (0.34-0.14\% MnO) and $\mathrm{P}(0.25-$ $0.29 \% \mathrm{P}_{2} \mathrm{O}_{5}$ ) are also detected (Table 2);

$45-75 \mathrm{~cm}$ : yellowish red horizon (5YR4/4) with a clayey texture and fine polyhedral structure. Mineralogically, the horizon differs from the 
previous one essentially by the appearance of hematite (Table 1). Geochemically, Al remains the most represented element as at the base of the profile $\left(34.00 \% \mathrm{Al}_{2} \mathrm{O}_{3}\right)$, followed by $\mathrm{Si}(23.80 \%$ $\begin{array}{lllll}\left.\mathrm{SiO}_{2}\right) & \text { and } \mathrm{Fe} & (8.75 \% & \left.\mathrm{Fe}_{2} \mathrm{O}_{3}\right) & \text { (Table 2). The }\end{array}$ horizon has in addition small quantities of $\mathrm{Ti}$ $\left(1.08 \% \mathrm{TiO}_{2}\right)$ and $\mathrm{K}\left(0.60 \% \mathrm{~K}_{2} \mathrm{O}\right)$, associated to more modest quantities of $\mathrm{P}\left(0.32 \% \mathrm{P}_{2} \mathrm{O}_{5}\right), \mathrm{Mn}$ (0.30\% $\mathrm{MnO}), \mathrm{Mg}(0.29 \% \mathrm{MgO})$ and $\mathrm{Na}(0.20 \%$ $\left.\mathrm{Na}_{2} \mathrm{O}\right)$; $\mathrm{Ca}$ is almost absent $(0.08 \% \mathrm{CaO})$ (Table 2);

0-45 cm: humiferous horizon, black (2.5YR2.5/0) and porous, with loamy texture and blocky structure. Mineralogical composition remains quite unchanged with gibbsite and allophanes, associated with small amounts of halloysite, ferrihydrite, goethite, hematite, rutile, magnetite and quartz (Table 1). Geochemically, $\mathrm{Si}$ and $\mathrm{Al}$ are the most important elements $\left(21.50 \% \mathrm{SiO}_{2}\right.$ and $\left.20.30 \% \mathrm{Al}_{2} \mathrm{O}_{3}\right)$, followed by $\mathrm{Fe}(7.05 \%$ $\mathrm{Fe}_{2} \mathrm{O}_{3}$ ) (Table 2). In addition to these three main elements, small amounts of $\mathrm{Ti}(0.97 \%$ $\left.\mathrm{TiO}_{2}\right), \mathrm{K}\left(0.48 \% \mathrm{~K}_{2} \mathrm{O}\right), \mathrm{P}\left(0.35 \% \mathrm{P}_{2} \mathrm{O}_{5}\right), \mathrm{Mg}$ $(0.30 \% \mathrm{MgO}), \mathrm{Ca}(0.23 \% \mathrm{CaO})$ and $\mathrm{Na}$ $\left(0.15 \% \mathrm{Na}_{2} \mathrm{O}\right)$ were detected (Table 2$)$.

Finally, the studied soils are characterised by a small thickness $\sim 2 \mathrm{~m}$, a thick humiferous superficial horizon, and a mixture of crystallized, paracrystalline and amorphous minerals, mainly gibbsite, halloysite and allophanes, which are conveyed geochemically by the presence of Al, Si and Fe.

\subsection{Methods}

The behaviour of $\mathrm{Fe}, \mathrm{Al}, \mathrm{Si}$, throughout the profile has been approached by calculating elements mass balances

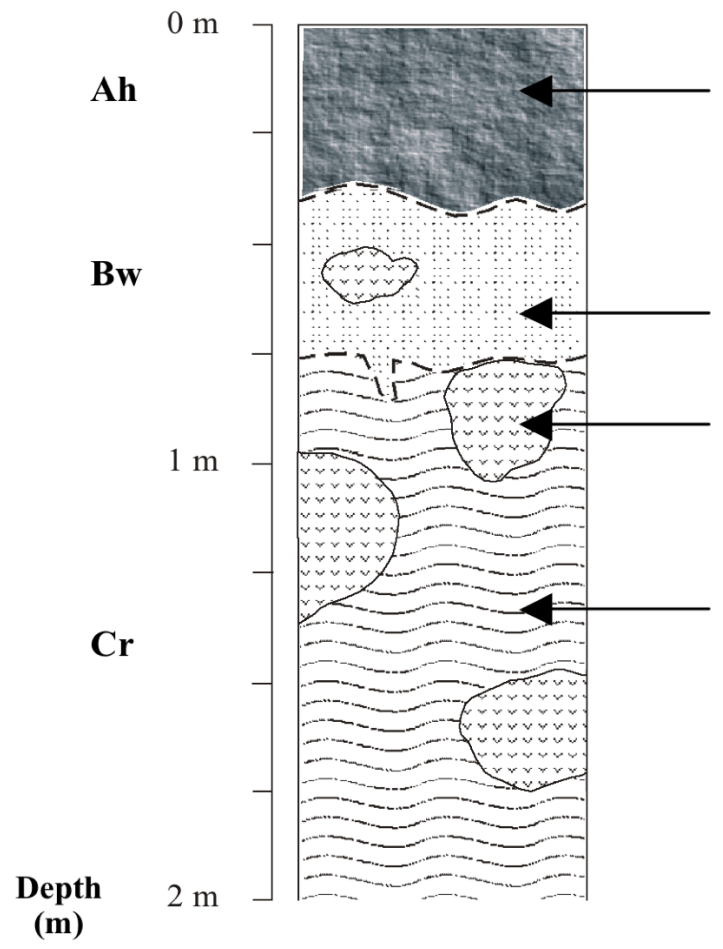

during pedogenesis. These mass balances have been carried out following the calculated 'mass balance method' [19-21] by considering titanium as an invariant element [22-24]. It is based on the residual enrichment in closed systems and supergene enrichment in open systems, which previously need the determination of horizon deformation rates. Horizon deformation rate $(\varepsilon)$, element mobilization rate $(\tau)$ and total mass of mobilized elements (m) in each horizon are calculated according to the following formulae:

$$
\begin{aligned}
& \varepsilon_{a}=\frac{C_{i, p} \cdot d_{p}}{C_{i, a} \cdot d_{a}}-1 ; \tau_{j, a}=\frac{d_{a}}{d_{p}} \frac{C_{j, a}}{C_{j, p}}\left(\varepsilon_{a}+1\right)-1 \\
& m_{j, a}=\left(\frac{C_{j, p}}{100} d_{p} . V_{p}\right) \tau_{j, a} \quad \text { in } \mathrm{g} / \mathrm{cm}^{3} ; \mathrm{v}_{\mathrm{p}}=1 \mathrm{~cm}^{3}[19]
\end{aligned}
$$

In these formulae, $\mathrm{C}_{\mathrm{i}, \mathrm{p}}$ and $\mathrm{C}_{\mathrm{i}, \mathrm{a}}$ are the concentrations of an invariant element $\mathrm{i}$ (here, $\mathrm{Ti}$ ) respectively in the parent rock $\mathrm{p}$ and the horizon $\mathrm{a} ; \mathrm{Cj}_{\mathrm{p}}$ and $\mathrm{Cj}_{\mathrm{a}}$ are concentrations of any common element $j$, respectively, in the parent rock $p$ and the horizon $\mathrm{a} ; \mathrm{d}_{\mathrm{p}}$ and $\mathrm{d}_{\mathrm{a}}$ are, respectively, the bulk density of the parent rock $\mathrm{p}$ and the horizon $\mathrm{a} ; \mathrm{V}_{\mathrm{p}}$ is the parent rock volume which corresponds to $1 \mathrm{~cm}^{3}$ [19].

The identification and the quantification of $\mathrm{Fe}$ forms have been achieved through selective extractions by citratebicarbonate with or without dithionite (CBD or CB) and by oxalic acid (Tamm, 1922 in Temgoua, 2001 [24].). CBD, oxalic acid and $\mathrm{CB}$ reagents, respectively, extract total free $\mathrm{Fe}$ forms $\left(\mathrm{Fe}_{\mathrm{CBD}}\right)$, amorphous forms $\left(\mathrm{Fe}_{\mathrm{Ox}}\right)$ and organic amorphous forms $\left(\mathrm{Fe}_{\mathrm{CB}}\right)$. Non-extractable $\mathrm{Fe}$ forms $\left(\mathrm{Fe}_{\mathrm{total}^{-}}\right.$ $\left.\mathrm{Fe}_{\mathrm{CBD}}\right)$, commonly attributed to iron included into silicate crystalline structure, will be considered here as 'resistant' iron forms according to Gaviria (1993) [25]. The fifth Fe form that can be identified is the well crystallized one; it is
Humiferous black horizon, loamy, blocky, porous; light-weight, brittle and fairly fragile aggregates.

Yellowish red clayey horizon with fine polyhedral matrix structure.

Blocks of trachyte rocks with rough surfaces.

Saprolitic horizon with yellow brown and whitish grey domains.

Fig. (2). Macroscopic organization of the studied Andosolic soil profile. 
Table 1. Mineralogical Composition of Soils

\begin{tabular}{|c|c|c|c|c|c|c|c|c|c|c|c|c|c|c|}
\hline \multicolumn{4}{|c|}{ Minerals } & Sa & Мa & Ha & All & $\mathbf{G i}$ & Goe & $\mathrm{He}$ & Feh & Ru & Ilm & $\mathbf{Q}$ \\
\hline \multicolumn{3}{|c|}{ Black humiferous horizon $(0-0.45 \mathrm{~m})$} & $\mathbf{A h}$ & / & + & + & ++ & +++ & + & + & + & + & l & + \\
\hline \multirow{2}{*}{$\begin{array}{l}\text { Saprolitic horizon } \\
(0.75-2 \mathrm{~m})\end{array}$} & \multirow{2}{*}{$\mathrm{Cr}$} & Yellow brown do & nain & / & + & ++ & ++ & ++++ & ++ & / & / & + & / & + \\
\hline & & Whitish grey dor & & + & + & ++ & + & ++++ & I & l & + & / & + & + \\
\hline
\end{tabular}

/: non identified; +: traces; ++: very deficient; +++: deficient; ++++: abundant; ++++: very abundant

Gi: gibbsite; Goe: goethite; Q: quartz; He: Hematite; Ha: halloysite; Ilm: ilmenite; Sa: sanidine; Ma: magnetite; Ru: rutile; All: allophanes; Feh: ferrihydrite.

Table 2. Chemical Composition of Soils and Parent Rock

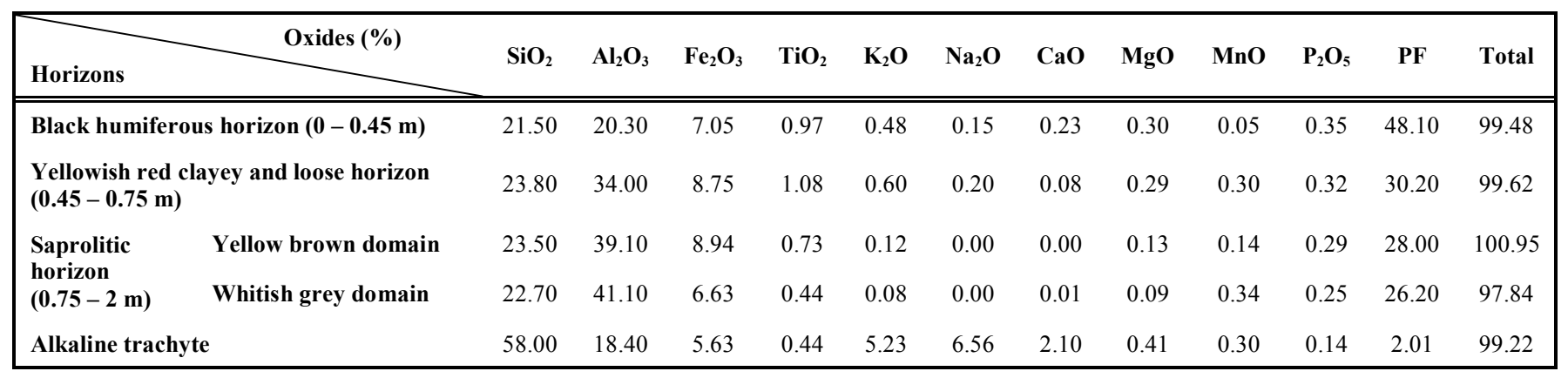

obtained by subtracting amorphous forms $\left(\mathrm{Fe}_{\mathrm{Ox}}\right)$ from total free forms $\left(\mathrm{Fe}_{\mathrm{CBD}}\right)$. Note that total iron $\left(\mathrm{Fe}_{\mathrm{Total}}\right)$ represents the whole amounts of $\mathrm{Fe}$ of a sample, including all Fe forms. It has been obtained by X-ray fluorescence on pressed powder pellets, using a Philips PW 2400 instrument with a rhodium anode end window tube, in the Mineral Analysis Centre at the Polytechnic Institute of Lausanne in Switzerland. The $\mathrm{Fe}_{\text {Total }}$ values of all the studied samples are presented in Table 2.

The three reagents, $\mathrm{CBD}, \mathrm{CB}$ and oxalic acid, which are specific of soil iron forms, can be extended to the study of $\mathrm{Al}$ forms, but only on the amorphous ones which they dissolved $[26,27]$. In consequence, total free $\mathrm{Al}$ does not include crystallized forms like gibbsite or boehmite. The previous chemical extractants are ineffective on $\mathrm{Si}$ [28], and the difference between Si extracted with CBD and Si extracted with oxalic acid is generally negative [28, 29]. For these reasons, the notion of extracting forms of $\mathrm{Si}$ has not been approached here. Supernatants from chemical extractions obtained by CBD ( $1 \mathrm{~g}$ of soil $+50 \mathrm{ml}$ of CB solution $+1 \mathrm{~g}$ of dithionite), $\mathrm{CB}$ (1 $\mathrm{g}$ of soil $+50 \mathrm{ml}$ of $\mathrm{CB}$ solution) and oxalic acid (1 $\mathrm{g}+40 \mathrm{ml}$ of oxalic acid solution) were decanted and analysed by atomic absorption spectrometer. Those selective extractions have been carried out in the "Laboratoire d'Analyses des Sols, Plantes, Engrais et Eaux (LASPEE)" of the Institute of Agricultural Research for Development (IRAD) of Yaoundé (Cameroon).

Soil mineralogy was investigated with a Philips X-ray diffractometer, using a copper anode with a characteristic wavelength of $1.54 \times 10^{-10} \mathrm{~m}(40 \mathrm{kV}$ source $)$ and a xenon $\mathrm{X}$ ray detector, in the Mineral Analysis Centre at the Polytechnic Institute of Lausanne in Switzerland. Amorphous and paracrystalline minerals have been identified by IR spectroscopy in the "Laboratoire de Minéralogie Cristallographie de Paris Jussieu" in France.
The determination of $\mathrm{pH}$ and potential redox (Eh) has been done in the same solution (soil/solution ratio $\frac{1}{2.5}$ ) using a direct reading $\mathrm{pH}$ meter HQ11D in the Wastewater Research Unit of the Faculty of Science (University of Yaoundé I, Cameroon). The redox level $\mathrm{rH}_{2}$ has been calculated using the formula $\mathrm{rH}_{2}=\frac{E h+0.06 p H}{0.03}$ [30].

\section{RESULTS}

\subsection{Behaviour of Iron, Aluminium and Silicon in the Studied Soils}

In the saprolitic horizon, $\mathrm{Si}$ is highly depleted out of the profile. Its mobilisation rate varies between $-61 \%$ in the whitish grey domain and $-75 \%$ in the yellow brown domain (Table 3), thus mean value of $-68 \%$ (Fig. 3a), which corresponds to a mobilized mass of $\sim 1.89 \mathrm{~g} / \mathrm{cm}^{3}$ (Fig. 4a). Al and $\mathrm{Fe}$ on the other hand are imported in the weathering horizons. Their importation rates fluctuate respectively, from $123-29 \%$ and from 18 to $-4 \%$ (Table 3 ), thus mean values of $76 \%$ for $\mathrm{Al}$ and $7 \%$ for Fe (Fig. 3a), which correspond, respectively, to a mobilized mass of 0.67 and $0.02 \mathrm{~g} / \mathrm{cm}^{3}$ (Fig. 4a).

In the yellowish red clayey horizon, $\mathrm{Si}, \mathrm{Al}$ and $\mathrm{Fe}$ are all depleted out of the profile. Their depletion rates are, respectively, $-83,-35$ and $-37 \%$ (Table $\mathbf{3}$ and Fig. 3b), corresponding, respectively, to a mobilized mass of -1.15 , 0.11 and $-0.05 \mathrm{~g} / \mathrm{cm}^{3}$ (Table 4 and Fig. 4b). Si is equitably depleted in the loose yellowish red clayey horizon and in the black humiferous horizon (Table 3; Fig. 3b, 3c). Al and Fe, although their negative rate, are most highly depleted in the humiferous horizon than in the loose yellowish red clayey horizon (-50\% and $-43 \%$, respectively) (Table 3 and Fig. 3c). 
Table 3. Bulk Density and Element Mobilization Ratios in the Horizons

\begin{tabular}{|c|c|c|c|c|c|c|}
\hline \multicolumn{2}{|l|}{ Horizons } & $D b\left(g / \mathrm{cm}^{3}\right)$ & $\varepsilon-\mathbf{T i}$ & $\tau \mathrm{Si}$ & $\tau \mathbf{A l}$ & $\tau \mathrm{Fe}$ \\
\hline \multicolumn{2}{|l|}{ Black humiferous horizon $(0-0.45 \mathrm{~m})$} & 0.64 & 0.70 & -0.83 & -0.50 & -0.43 \\
\hline \multicolumn{2}{|c|}{ Yellowish red clayey and loose horizon $(0.45-0.75 \mathrm{~m})$} & 1.00 & -0.02 & -0.83 & -0.35 & -0.37 \\
\hline \multirow{2}{*}{ Saprolitic horizon $(0.75-2 \mathrm{~m})$} & Yellow brown domain & 1.10 & 0.32 & -0.75 & 0.29 & -0.04 \\
\hline & Whitish grey domain & 1.7 & 0.41 & -0.61 & 1.23 & 0.18 \\
\hline \multicolumn{2}{|c|}{ Alkaline trachyte } & 2.4 & 0 & 0 & 0 & 0 \\
\hline
\end{tabular}

Db: bulk density; $\varepsilon$-Ti: deformation ratio at Ti constant; $\boldsymbol{\tau}$ : relative enrichment ratio of an element in comparison with the parent rock.

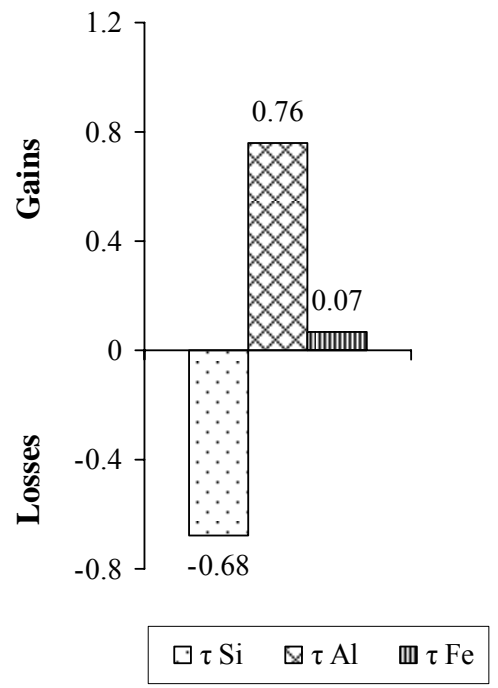

a)

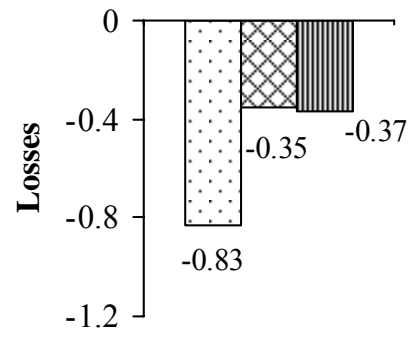

$\square \tau \mathrm{Si} \otimes \tau \mathrm{Al} \quad$ 血 $\tau \mathrm{Fe}$

b)

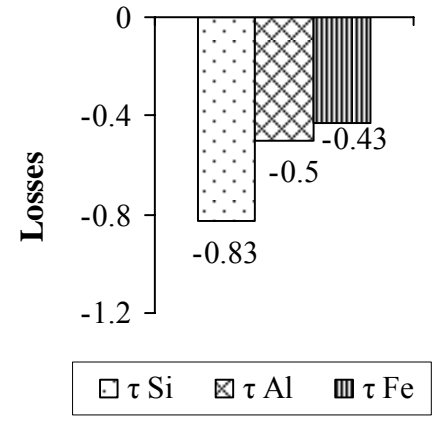

c)

Fig. (3). Mobilization rate of silicon, aluminium and iron in the saprolitic horizons (a), in the yellowish red clayey and loose horizon (b), in the black humiferous horizon (c) of studied soils.

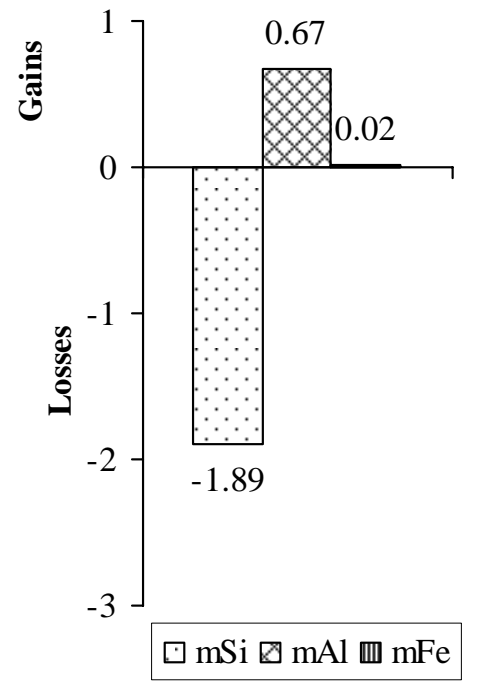

a)

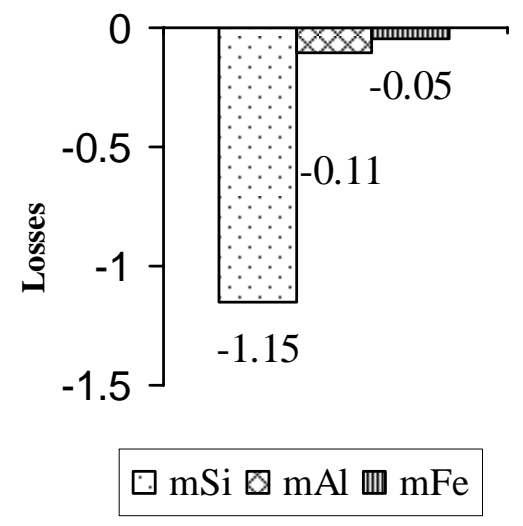

b)

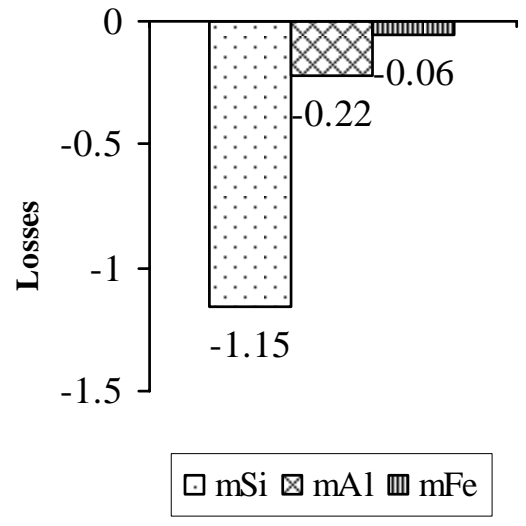

c)

Fig. (4). Total mass of silicon, aluminium and iron in the saprolitic horizons (a), in the yellowish red clayey and loose horizon (b), in the black humiferous horizon $(\mathbf{c})$ of studied soils. 
Table 4. Mobilized Mass (m) of Elements in the Horizons $\left(\mathrm{g} / \mathrm{cm}^{3}\right)$

\begin{tabular}{|c|c|c|c|c|}
\hline Horizons & Elements & $\mathbf{m S i}$ & mAl & $\mathrm{mFe}$ \\
\hline \multicolumn{2}{|c|}{ Black humiferous horizon $(0-0.45 \mathrm{~m})$} & -1.155 & -0.221 & -0.058 \\
\hline \multicolumn{2}{|c|}{ Yellowish red clayey and loose horizon $(0.45-0.75 \mathrm{~m})$} & -1.155 & -0.110 & -0.050 \\
\hline Saprolitic horizon & Yellow brown domain & -1.044 & 0.128 & -0.005 \\
\hline$(0.75-2 \mathrm{~m})$ & Whitish grey domain & -0.849 & 0.543 & 0.024 \\
\hline Sum & & -4.203 & 0.340 & -0.089 \\
\hline
\end{tabular}

Total mass of exported elements: $-5.52 \mathrm{~g} / \mathrm{cm}^{3}$ (include $\mathrm{Ca}, \mathrm{Mg}, \mathrm{K}, \mathrm{Na}$ and $\mathrm{Mn}$ which are also depleted from the profile); Total mass of imported elements: $0.344 \mathrm{~g} / \mathrm{cm}^{3}$ (include $\mathrm{P}$ which is also imported into the profile).

Fe and $\mathrm{Al}$ are then imported at the base of the profile, but depleted in the upper part, while $\mathrm{Si}$ is depleted throughout the profile. The global balance of $\mathrm{Fe}$ is however negative and its value is $-16 \%$; that value corresponds to a total mobilized mass of $-0.089 \mathrm{~g} / \mathrm{cm}^{3}$ (Table 4 and Fig. 5b) and represents $1.61 \%$ of the total mass of elements exported from the profile. Because Al is more highly enriched in the weathering horizon at the base of the profile, its global balance is in excess (17\%) (Fig. 5a) and its total mass mobilized is $0.34 \mathrm{~g} / \mathrm{cm}^{3}$ (Table $\mathbf{4}$ and Fig. $\mathbf{5 b}$ ); this value represents $98.84 \%$ of the total elements imported in the whole profile. The global balance of $\mathrm{Si}$ is negative, with mean value of $-75 \%$ (Fig. 5a), that corresponds to a total mobilized mass of $-4.203 \mathrm{~g} / \mathrm{cm}^{3}$ (Table 4 and Fig. 5b), representing $76.14 \%$ of the total mass of elements exported from the profile.

\subsection{Identification and Quantification of the Main Forms of Iron and Aluminium in the Studied Soils}

The different forms of $\mathrm{Fe}$ and $\mathrm{Al}$ identified are free, amorphous, crystallized and 'resistant' forms.

\subsection{1. 'Resistant' Forms}

The 'resistant' forms have only been identified for Fe. Their contents are high and fluctuate between $2.74-4.38 \%$ $\mathrm{Fe}_{2} \mathrm{O}_{3}$ (Table 5), and represent 59.03-69.96\% of the total $\mathrm{Fe}$ (Table 6). The highest value $\left(4.38 \% \mathrm{Fe}_{2} \mathrm{O}_{3}\right)$ is observed in the yellow brown domain, while the lowest one $(2.74 \%$ $\left.\mathrm{Fe}_{2} \mathrm{O}_{3}\right)$ is noted in the whitish grey domain of the saprolitic horizon (Table 5). However, a slight decrease is noted towards the surface (Table 5).

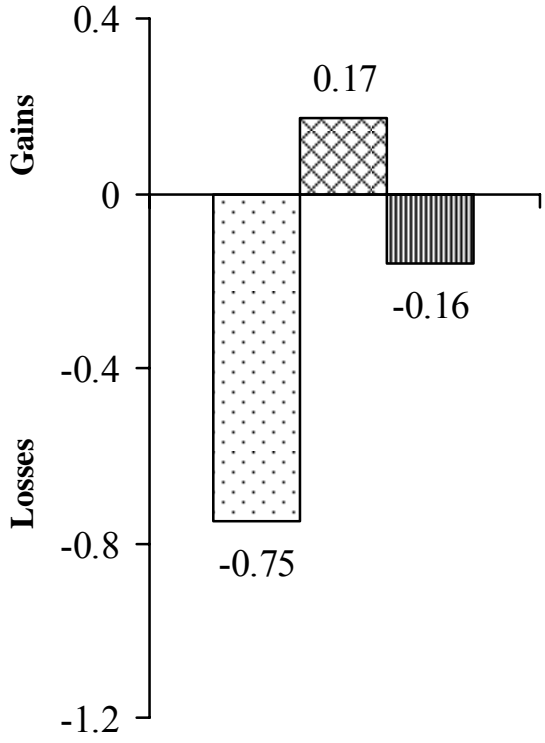

$\tau \mathrm{Si} \otimes \tau \mathrm{Al} \mathbf{m} \tau \mathrm{Fe}$

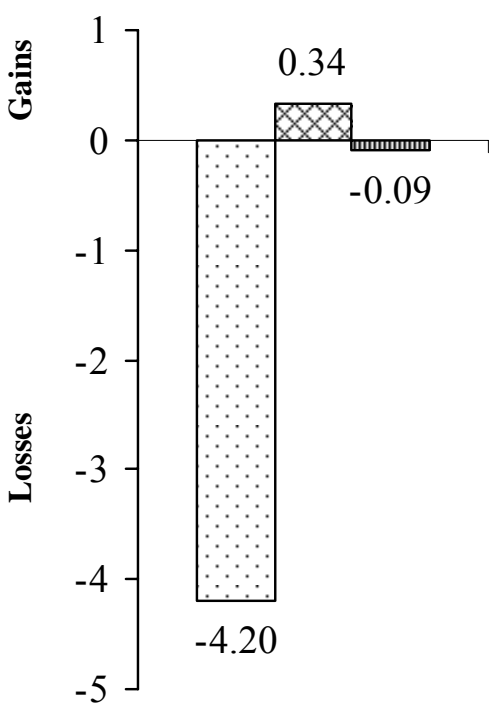

$\mathrm{mSi} \otimes \mathrm{mAl}$ m mFe

b)

Fig. (5). Mobilization rate (a) and total mobilized mass (b) of silicon, aluminium and iron in the studied soils. 
Table 5. Forms of Iron and Aluminium in the Studied Soils and their Contents

\begin{tabular}{|c|c|c|c|c|c|c|c|c|c|c|c|c|c|c|}
\hline \multirow{2}{*}{\multicolumn{2}{|c|}{ Horizons }} & \multirow{2}{*}{ 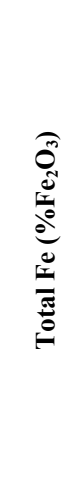 } & \multirow{2}{*}{ 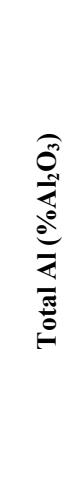 } & \multicolumn{2}{|c|}{ 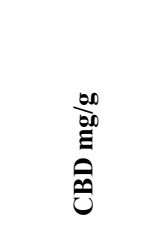 } & \multicolumn{2}{|c|}{$\begin{array}{l}\frac{00}{000} \\
\Xi \\
\Xi \\
0\end{array}$} & \multicolumn{2}{|c|}{ 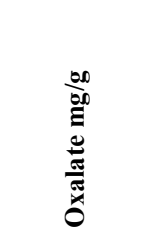 } & 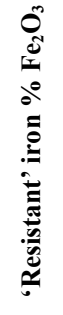 & 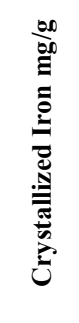 & \multirow{2}{*}{$\begin{array}{c}\frac{F e_{O x}}{F e_{C B D}} \\
\%\end{array}$} & \multirow{2}{*}{$\begin{array}{c}A l_{O x} \\
A l_{C B D} \\
\quad \%\end{array}$} & \multirow{2}{*}{ 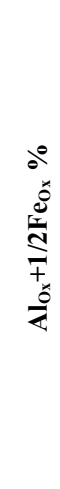 } \\
\hline & & & & 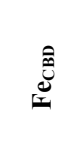 & $\frac{\hat{0}}{\gtrless}$ & $\underset{\mathscr{E}}{0}$ & $\stackrel{0}{\gtrless}$ & $\stackrel{0}{0}$ & $\stackrel{0}{4}$ & 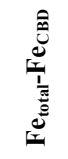 & 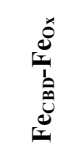 & & & \\
\hline \multicolumn{2}{|c|}{ Black humiferous horizon $(0-0.45 \mathrm{~m})$} & 4.94 & 10.75 & 17.20 & 6.88 & 0.01 & 1.72 & 0.40 & 1.95 & 3.22 & 16.80 & 2.33 & 28.34 & 0.22 \\
\hline \multicolumn{2}{|c|}{$\begin{array}{l}\text { Yellowish red clayey and loose horizon } \\
(0.45-0.75 \mathrm{~m})\end{array}$} & 6.13 & 18.00 & 18.80 & 4.70 & 0.02 & 1.20 & 0.41 & 1.81 & 4.25 & 18.39 & 2.18 & 38.51 & 0.21 \\
\hline \multirow{2}{*}{$\begin{array}{l}\text { Saprolitic } \\
\text { horizon } \\
(0.75-2 \mathrm{~m})\end{array}$} & Yellow brown domain & 6.26 & 20.70 & 18.80 & 5.87 & 0.01 & 1.54 & 0.43 & 2.34 & 4.38 & 18.37 & 2.29 & 39.86 & 0.26 \\
\hline & Whitish grey domain & 4.64 & 21.76 & 19.01 & 6.33 & 0.03 & 1.71 & 0.40 & 2.14 & 2.74 & 18.61 & 2.10 & 33.81 & 0.24 \\
\hline
\end{tabular}

\subsubsection{Total Free Forms}

\section{Total Free Iron}

Total free $\mathrm{Fe}\left(\mathrm{Fe}_{\mathrm{CBD}}\right)$ contents fluctuate between 17.20$19.01 \mathrm{mg} / \mathrm{g}$ (Table 5), representing 30.67-40.97\% of total Fe. The extractible iron forms are more important at the base of the profile $(19.01 \mathrm{mg} / \mathrm{g})$ than at the top of the profile $(17.20 \mathrm{mg} / \mathrm{g})$ (Table 5).

\section{Total Free Aluminium}

Total free $\mathrm{Al}\left(\mathrm{Al}_{\mathrm{CBD}}\right)$ includes only amorphous $\mathrm{Al}$ forms. It globally presents low contents; they vary between 4.70-6.88 $\mathrm{mg} / \mathrm{g}$ (Table 5) and represents $\sim 2.61-6.33 \%$ of total Al. The highest value is obtained in the humiferous horizon $(6.88 \mathrm{mg} / \mathrm{g})$, while the lower one is noted in the loose yellowish red clayey horizon $(4.70 \mathrm{mg} / \mathrm{g})$ (Table 5).

\subsubsection{Crystallized Forms}

\section{Crystallized Iron Forms}

Crystallized Fe forms contents range between 16.80-18.61 $\mathrm{mg} / \mathrm{g}$ (Table 5). The higher value, $18.61 \mathrm{mg} / \mathrm{g}$, is observed in the saprolitic horizon at the base of the profile, while the lower one is noted in the humiferous horizon at the upper part. Those contents represent $29.35-40.11 \%$ of total Fe (Table 6), and $97.67-97.90 \%$ of the total Fe free form extracted by CBD.

\section{Crystallized Aluminium Forms}

'Crystallized Al', by analogy to crystallized Fe, corresponds to the difference between $\mathrm{Al}_{\mathrm{CBD}}$ and $\mathrm{Al}_{\mathrm{Ox}}$; it constitutes 1.61$4.59 \%$ of the total $\mathrm{Al}$ and $60-71 \%$ of the total $\mathrm{Al}$ free form extracted by CBD (Table 6). These forms of Al are considered as Al included into iron in hematite or goethite networks [24, $25,27]$.

\subsubsection{Amorphous Forms}

\section{Amorphous Iron Forms}

The amorphous iron forms (Feox) are very poorly represented in the profile (Fig. 7). Their contents vary between $0.40-0.43 \mathrm{mg} / \mathrm{g}$ (Table 5 and Fig. 7), and represent $0.67-0.86 \%$ of total iron (Table 6), or $2.10-2.33 \%$ of the total free forms $\mathrm{F}_{\mathrm{CBD}}$ (Table 5). The amounts of $\mathrm{Fe}$ associated with organic matter (organic amorphous iron forms) are negligible (0.01-0.03 $\mathrm{mg} / \mathrm{g}$ ) (Table 5), compared to the mineral amorphous forms (Fig. 8a); it represents 2.50-7.50\% of the total amorphous Fe, while mineral amorphous $\mathrm{Fe}$ on the other hand, represents $92.50-97.50 \%$ of total amorphous Fe (Table 6).

\section{$\underline{\text { Amorphous Aluminium Forms }}$}

Amorphous Al is the best represented amorphous form in the studied soils (Table 5 and Fig. 6). Its contents oscillate between 1.81-2.34 mg/g (Table 5 and Fig. 6), representing $81.53-84.48 \%$ of total amorphous forms ( $\mathrm{Fe}$ and $\mathrm{Al}$ ) extracted by the oxalate reagent, or $0.98-1.81 \%$ of total alumina (Table 6). However, the form of Al linked to organic matter (organic amorphous $\mathrm{Al}$ forms), in the form of Al-humus complexes $\left(\mathrm{Al}_{\mathrm{CB}}\right)$, is better expressed than the mineral forms (Fig. 8b), contrary to Fe (Fig. 8a). Its contents vary slightly along the profile, between $1.20-1.72 \mathrm{mg} / \mathrm{g}$ (Table 5 and Fig. 8b), which represent $\sim 65.81-88.21 \%$ of the total amorphous Al forms, while the mineral fraction on the opposite only represents $11.79-34.19 \%$ (Table 6). The proportion of amorphous Al compared to the total free $\mathrm{Al}$ extracted by $\mathrm{CBD}$ is somewhat high and varies between 28.34-39.86\% (Table 5).

\section{$\underline{\text { Alox }+1 / 2 \text { Feox Ratio }}$}

The Alox $+1 / 2$ Feox ratio values are globally low. They vary between 0.21-0.26 (Table 5).

\subsection{Physical and Chemical Soil Parameters}

The soil $\mathrm{pH}$ values, which vary between 3.9-5.4 (Table 7), reveal an acidic nature with pronounced acidity in the black humiferous horizon (3.9). One can note that those values regularly decrease from the base to the upper profile. The redox potential values, contrary to the $\mathrm{pH}$ ones, increase 
Table 6. Forms of Iron and Aluminium in the Studied Soils and their Relative Contents

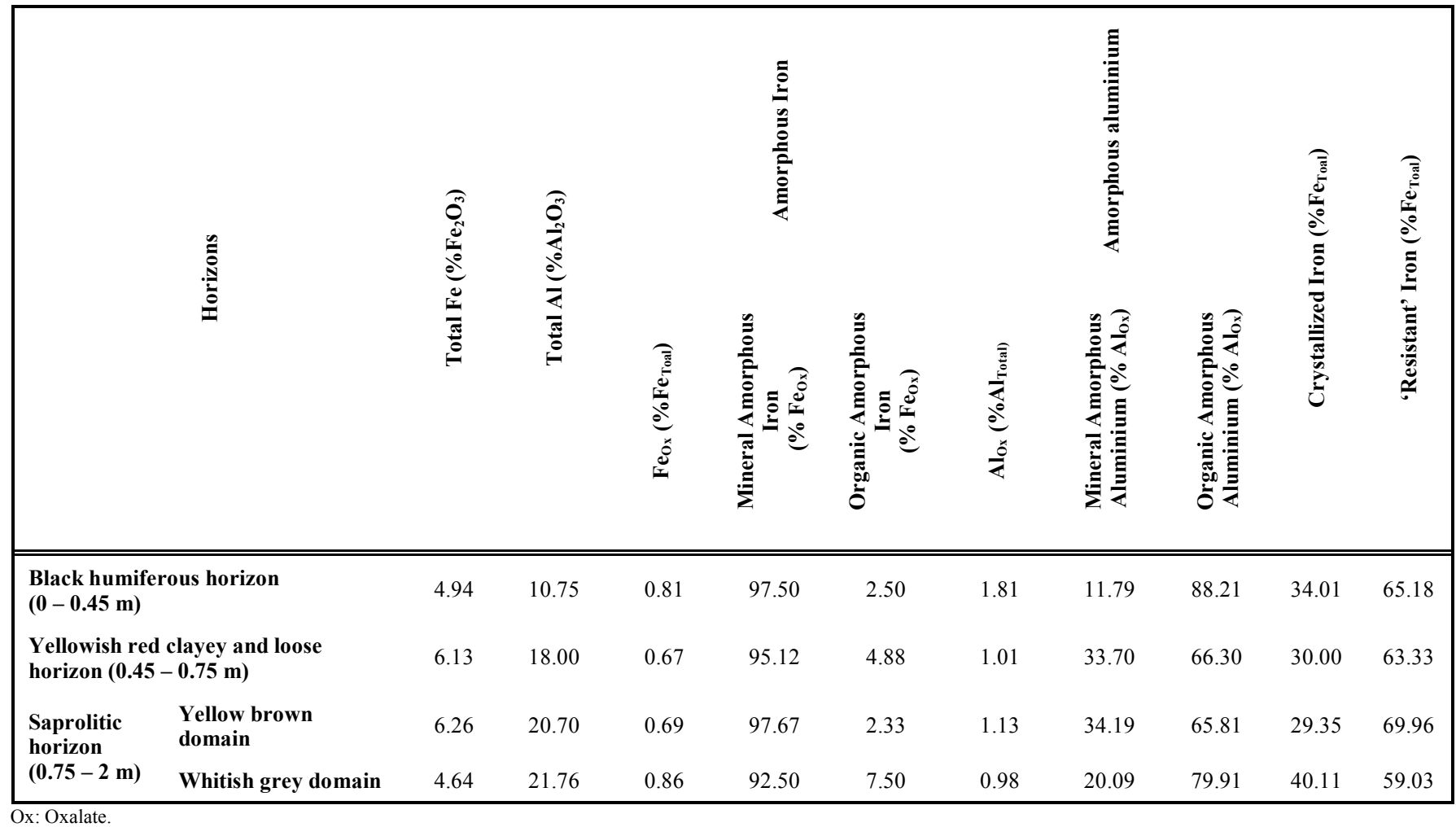

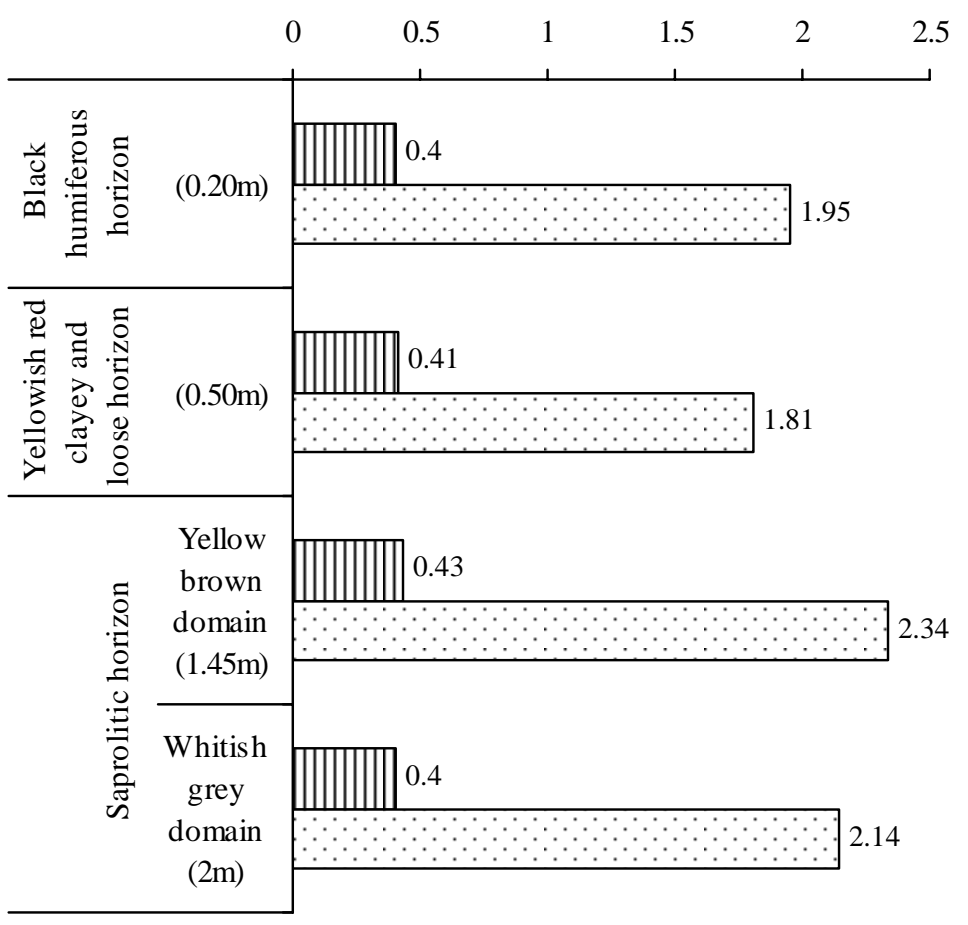

$\square$ Amorphous iron (mg/g) $\square$ Amorphous aluminium (mg/g)

Fig. (6). Comparison of amorphous forms of iron and aluminium extracted by oxalic acid in studied soils. 


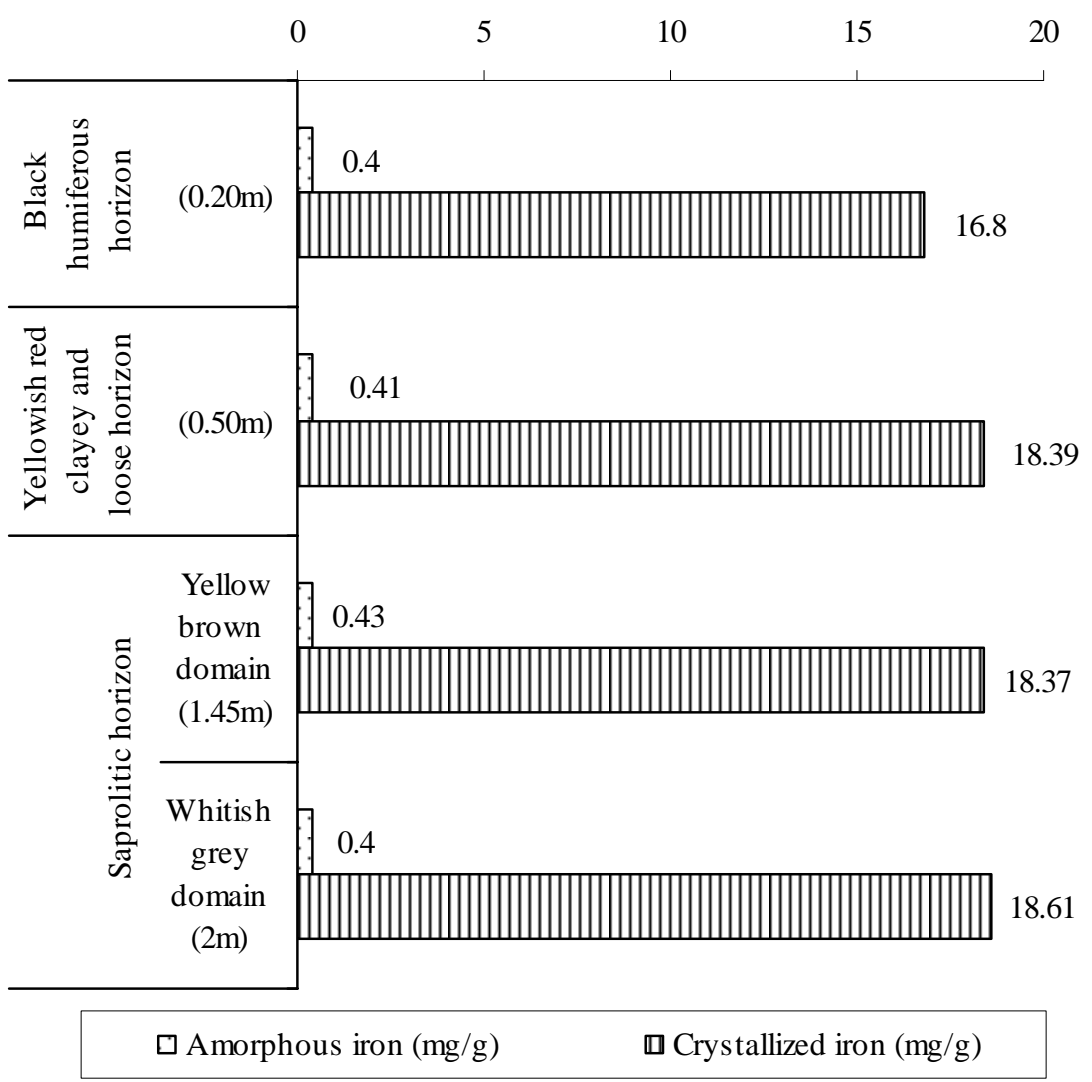

Fig. (7). Variation of amorphous and crystallized iron in studied soils.

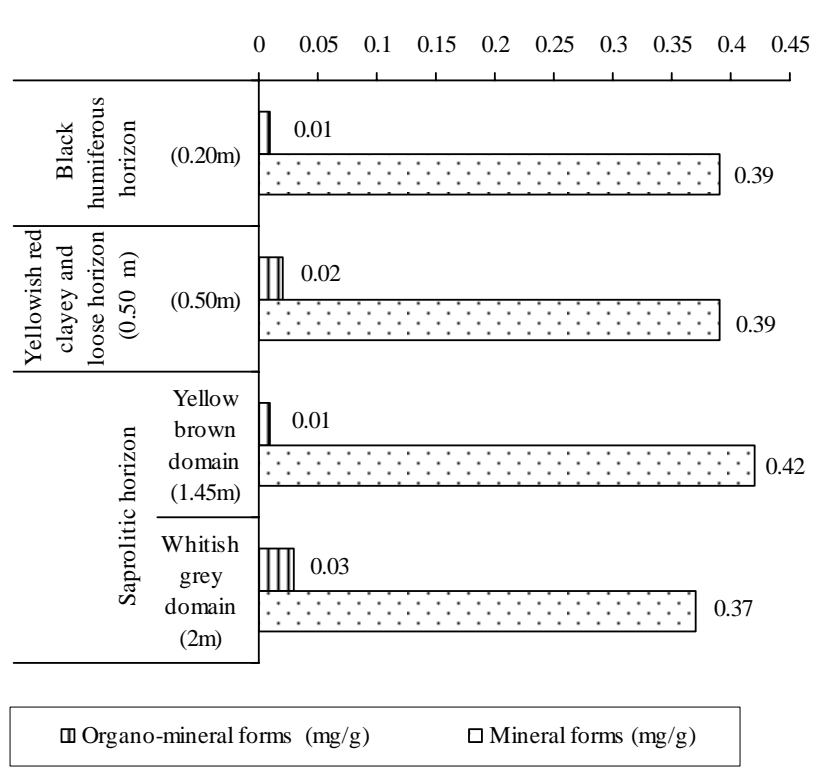

a)

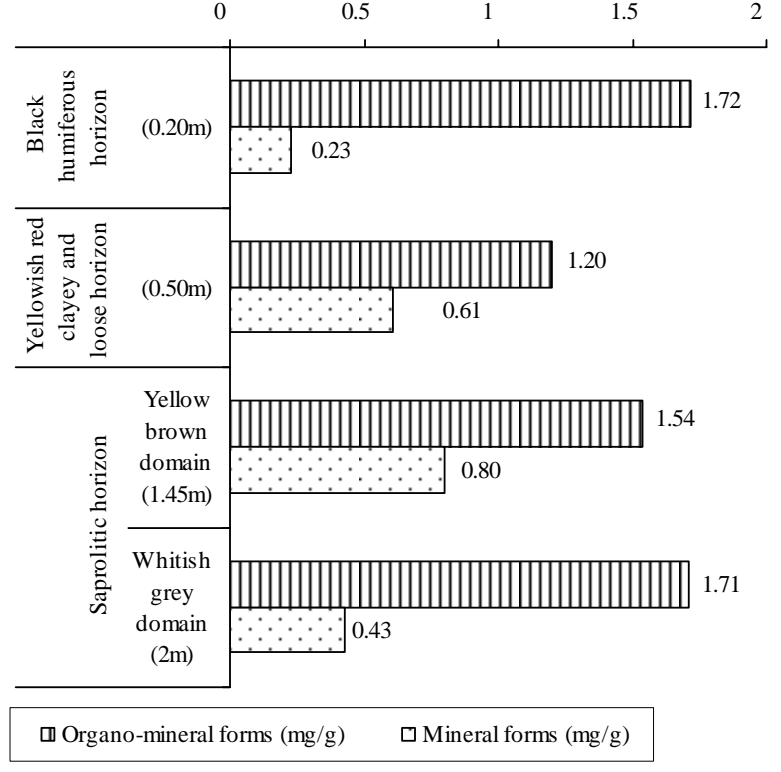

b)

Fig. (8). Variation of organo-mineral and mineral forms of amorphous iron (a) and amorphous aluminium (b) in the soil profile. 
Table 7. Physico-Chemical Characteristics of Soils

\begin{tabular}{|c|c|c|c|c|}
\hline & Horizons & pH & Eh (Volt) & $\mathbf{r H}_{2}$ \\
\hline \multicolumn{2}{|c|}{ Black humiferous horizon $(0-0.45 \mathrm{~m})$} & 3.9 & 0.18 & 13.8 \\
\hline \multicolumn{2}{|c|}{ Yellowish red clayey and loose horizon $(0.45-0.75 \mathrm{~m})$} & 5.0 & 0.12 & 14.0 \\
\hline \multirow{2}{*}{ Saprolitic horizon $(0.75-2 \mathrm{~m})$} & Yellow brown domain $(1.45 \mathrm{~m})$ & 5.3 & 0.10 & 13.9 \\
\hline & Whitish grey domain (2m) & 5.4 & 0.09 & 13.8 \\
\hline
\end{tabular}

from bottom to top, varying between $0.09-0.18 \mathrm{~V}$ (Table 7). The highest value, $0.18 \mathrm{~V}$, is recorded in the black humiferous horizon which is the most acidic one. The redox level, $\mathrm{rH} 2$, shows values ranging between 13.8-14.0 (Table 7).

\section{DISCUSSION AND INTERPRETATION}

The studied soils are mainly constituted by Al (20.30$\left.41.10 \% \mathrm{Al}_{2} \mathrm{O}_{3}\right)$, $\mathrm{Si}\left(21.50-23.80 \% \mathrm{SiO}_{2}\right)$ and $\mathrm{Fe}(6.63-8.94 \%$ $\mathrm{Fe}_{2} \mathrm{O}_{3}$ ), present essentially in the form of gibbsite, halloysite, allophane, goethite, hematite and ferrihydrite. Among these three elements, only Si is strongly leached in all horizons. Its leaching might have been accelerated by the incorporation of soil organic matter (SOM) [31], as confirmed by the high mobilization rate of $\mathrm{Si}$ obtained in the upper profile. This evacuation of $\mathrm{Si}$ is, however, contrary to the phenomenon which is observed in temperate zones, characterized by high accumulation of $\mathrm{Si}$ in the form of clay minerals, leading to bisiallitisation [32].

$\mathrm{Fe}$, despite its non-negligible contents (6.63-8.94\% $\mathrm{Fe}_{2} \mathrm{O}_{3}$ ), is enriched in the weathering horizon at the base of the profile $(18 \%)$, but depleted in the half upper part ( -37 to $43 \%$ ). Its mobilization rate increases from bottom to top. It presents a negative global balance and a total mobilized mass of $-0.089 \mathrm{~g} / \mathrm{cm}^{3}$, which globally remains relatively low. The evacuation of $\mathrm{Fe}$ from the profile agrees with the Eh and $\mathrm{rH}_{2}$ values (respectively, $<0.20 \mathrm{~V}$ and 20 ), which are favourable to its reduction [30]. This reduction is favoured by the presence of micro-organisms that cause SOM oxidation and maintain reducting conditions $[33,34]$. $\mathrm{Fe}$ is widely dominated by non-extractible $\mathrm{Fe}$ forms or resistant forms, which represent $\sim 60-70 \%$ of the total $\mathrm{Fe}$ in the studied soil. These high values are similar to those obtained in andosolic soils in the Nilgiri Highlands of India [15] and podzolic soils of Brazil [28]. It is represented in the studied soils mainly by magnetite and ilmenite which are clearly identified in those soils and well known as non-extractible minerals [35]. Those 'resistant' iron minerals, which are fairly inert, are mostly inherited from the parent rock. Fe seems to be indifferent to the soil evolution processes, contrary to its well known role in ferrallitic soils for example [24, 35]. This might mainly be the result of the high presence of 'resistant' $\mathrm{Fe}$ forms. Among the extractible forms, crystallized ones are the most important fraction (29-40\%), represented mainly by hematite and goethite. The amorphous $\mathrm{Fe}$ contents are low and constant throughout the profile, $0.40-0.43 \mathrm{mg} / \mathrm{g}$, values which correspond to $0.67-0.86 \%$ of the total Fe and 2.10 2.33 of total extractible Fe. The amorphous Fe associated with SOM extracted by $\mathrm{CB}$ reagent is almost negligible (2.50-7.50 of total amorphous $\mathrm{Fe}$ ), indicating that most amorphous $\mathrm{Fe}$ is in mineral form (Fig. 6a), probably in the form of ferrihydrite, as identified in the studied soils.

$\mathrm{Al}$, as with $\mathrm{Fe}$, is enriched in the weathering horizon (29$123 \%)$, but depleted in the upper part profile ( -35 to $-50 \%)$. Its mobilization rate increases from bottom to top, a behaviour similar to Fe. The global balance of this element is in excess and the total mass mobilized in the studied soils is $0.34 \mathrm{~g} / \mathrm{cm}^{3}$. The depletion of $\mathrm{Al}$ in the upper profile might be attributed to acid $\mathrm{pH}$ (3.9) which is unfavourable to the stability of Al oxide [36]. Amorphous Al forms are 4-5 times higher than amorphous Fe forms (Fig. 6a). The amorphous $\mathrm{Al}$ fraction associated with $\mathrm{SOM}\left(\mathrm{Al}_{\mathrm{CB}}\right)$ is equally remarkable in its amounts (66-88\% of total amorphous Al), contrary to mineral amorphous forms, which are weakly represented. This amorphous mineral is probably in the form of allophane, as identified in mineralogical analyses. The presence of allophane characterizes the processes of andosolisation which occur in this volcanic environment. However, this process is weakly expressed as testified by the low Al amorphous mineral form contents and the Alox $+1 / 2$ Feox ratio, which values vary between $0.21-0.26 \%$ (Table 5), and are characteristic of very weakly allophanic soils [37]. The low pH in the upper profile (3.9) and the high SOM content might inhibit allophanes formation [15]. The decreasing gradient of relative Al enrichment towards the surface $\left(123 \%\right.$ at the bottom of the profile and $-50 \% \mathrm{Al}_{2} \mathrm{O}_{3}$ in the humiferous surface horizon) might be partly attributed to the acido-complexolysis of gibbsite and the production of $\mathrm{Al}$ organo-metallic forms [15]. Amorphous Al contracts then close links with organic matter and causes its insolubilization by the formation of compounds which are resistant to biodegradation [38-43, 15], leading to the high residence time, up to several thousand years even values approaching 30000 years [44-46] and then the persistence of a thick black surface humiferous horizon.

Generally, the acidic $\mathrm{pH}$ and weakly redox potential cause strong mobilization of $\mathrm{Si}$ and $\mathrm{Fe}$, concomitantly with high accumulation of $\mathrm{Al}$ in the soils [31, 25]. The strong occurrence of Al could permit describing these soils as Aluandosols using the "Reférentiel de Pédologie Français" [47]. Globally, two zones can be distinguished in the profile. Firstly, the two upper horizons considered as an eluviation zone (loss of $\mathrm{Si}, \mathrm{Al}$ and $\mathrm{Fe}$ ), in which $\mathrm{pH}$, Eh and $\mathrm{rH} 2$ are, respectively, 3.9-5.0, 0.12-0.18 and 13.8-14. Secondly, the weathering horizon at the base of the profile, considered as an illuviation zone (accumulation of $\mathrm{Al}$ and $\mathrm{Fe}$ ), in which $\mathrm{pH}$, Eh and $\mathrm{rH} 2$ are, respectively, 5.3-5.4, 0.09-0.10 and 13.8-13.9 (Table 7). Despite the environmental conditions of the mountainous massifs which are similar to those of high latitudes temperate zones, the crystallochemistry processes 
are very different, with a clear general tendency to bisiallitisation in the second case, but monosiallitisation associated to high allitisation [32] in these tropical mountainous environments, as testified by the high evacuation of $\mathrm{Si}$ and bases, and the strong accumulation of $\mathrm{Al}$ in the profile. This might be attributed to high rainfall volume and uneven relief which promote excellent drainage [31].

\section{CONCLUSIONS}

The soils of the upper part of Bambouto Mountain are characterized by a high evacuation of $\mathrm{Si}$ and a moderate evacuation of $\mathrm{Fe}$ out of the profile, a high accumulation of $\mathrm{Al}$ and a strong occurrence of Al-humus complexes. 'Resistant' Fe forms are strongly represented. Extractible Fe fraction is dominated by crystallized Fe forms, which is associated with small quantities of mineral amorphous form identified mainly as ferrihydrite. Fe links to SOM are negligible. Extractible Al fraction on the opposite is dominated by organic amorphous in the form of Al-humus complexes, associated with small quantities of mineral amorphous fraction, mainly in the form of allophane. The behaviour of the three elements and the forms in which they are present in the studied soil are globally controlled by $\mathrm{pH}$ and Eh values, which are favourable to their movement and stabilisation. Although the environmental conditions (climate, vegetation,...) are similar to those of the temperate zone, the biogeochemical functioning of the tropical mountainous soils remains very different. There is a high allitisation associated to andosolisation on volcanic rocks in the mountainous zone, but bisiallitisation on all rock types associated with podzolisation, andosolisation or brunification in the temperate zone.

\section{ACKNOWLEDGEMENTS}

The authors thank Dr Emile Temgoua and Dr Paul Tematio for the different mineralogical and geochemical analyses. We are also glad for the comments and suggestions of the three anonymous referees who have substantially improved the quality of this paper.

\section{REFERENCES}

[1] T.E. Jordan, and R.W. Allmendinger, "The sierras Pampeanas of Argentina: a modern analogue of rocky mountain foreland deformation", Am. J. Sci., vol. 286, n 10, pp. 737-764, 1986.

[2] A.H.J. Mitchell, and A. Warden, "Geological evolution of the New Hebrides Island Arc", J. Geol. Soc. Am., vol. 127, pp. 501-529, 1971.

[3] H. Colley, and A. Warden, "Petrology of new Hebrides", J. Geol. Soc. Am., vol. 85, pp.1635-1646, 1974.

[4] C. Downie, and P. Wilkinson, The Geology of Kilimandjaro. England: University Sheffield, Department of Geology, 1972.

[5] J. N'ni, "Mount Cameroon active volcano (Cameroon volcanic line): Geology and petrology of the volcano", thèse $3^{\text {ème }}$ cycle, Université de Paris-Sud, Centre d'Orsay, Paris, France, 1984.

[6] F. M. Tchoua, "Contribution to geological and petrological study of some volcanoes along the Cameroon volcanic line (mount Manengouba and Bambouto)", thèse d'Etat, Université de Clermond Ferrand, Clermond Ferrand, France, 1974.

[7] D. Youmen, "Volcanic, petrologic and temporal evolution of mount Bambouto caldera (Cameroon)", thèse Doct., Université C.A. Kiev, Kiev, Ukraine, 1994.

[8] J. N'ni, and J.B. Nyobé, "Geology and petrography of mount Bambouto precalderic lavas: Cameroon volcanic line", Geochim. Brasil, vol. 9, n 1, pp. 45-59, 1995.

[9] I.H. Bisseck, Ed., Karthala. Paris,1995.
[10] Koechlin, "Tropical flora and vegetation", in Man and Tropical Mountain Review, Sepanrit, Bordeaux, 1988, pp. 25-27.

[11] S. Morin, "Fundamental dissymmetries of the western Cameroon highlands and their consequences on human occupancy. Case of mount Bambouto", in Man and Tropical Mountain Review, Sepanrit, Bordeaux, 1988, pp. 29-59.

[12] F. Colmet-Daage, C. Kimpe, M. Delaune, G. Sieffermann, J. Gautheyrou, M. Gautheyrou, G. Fusil, and M. Koukoui, "Characteristics of some Ecuador soils derived from volcanic ash. $3^{\text {rd }}$ part: comparative view of some warm tropical and cold temperate altitudinal soils", Cah. ORSTOM, sér. Pédol., vol. 7, n 4, pp. 495-560, 1969.

[13] G. Sieffermann, "Soils of some Cameroon volcanic regions. Pedological variations from equatorial to tropical zone", thèse Doct. Université de Strasbourg, Strasbourg, France, 1973.

[14] P. Quantin, "Volcanic archipelago soils of New Hebrides (Vanuatu). Study of initial pedogenesis in the tropical zone", thèse Doct. Université de Strasbourg, Strasbourg, France, 1991.

[15] L. Caner, "Humiferous soils of Nilgeri massif highlands in South India. Andosols formation on an ancient ferrallitic cover in relation with the last millenary climatic evolutions", thèse Doct. Université Henri Poincaré-Nancy I, Nancy, France, 2000.

[16] P. Tematio, L. Kengni, D. Bitom, M. Hodson, J.C. Fopoussi, O. Leumbe, H.G. Mpakam, and D. Tsozué, "Soils and their distribution in Bambouto volcanic mountain, West Cameroon Highlands, Central Africa", J. Afr. Earth Sci., vol. 39, pp. 447-457, 2004.

[17] P. Tematio, "Petrologic and cartographic study of andic and ferrallitic soils in a humid tropical mountain region (case of Bambouto volcanic mountain in the western Cameroon highlands): influence of lithology and environmental conditions", thèse Doct. d'Etat, Université de Yaoundé I, Yaoundé, Cameroun, 2005.

[18] V. Rosello, "Mineralogical and microstructural characterisations of andosolic soils. Experimental reconnaissance of their behaviour", thèse Doct., Université de Paris VII, Paris, France, 1984.

[19] G.H. Brimhall, C.N. Alpers, and A.B. Cunningham, "Analysis of supergene ore-forming processes and grand-water solute transport using mass balance principles", Econ. Geol, vol. 80, n5, pp.12271256, 1985.

[20] G.H. Brimhall, C.J. Lewis, J.J. Ague, W.E. Dietrich, J. Hampel, T. Teague, and P. Rix, "Metal enrichment in bauxites by deposition of chemically mature aeolian dust", Nature, Vol. 333, pp. 819-824, 1988.

[21] F. Colin, G.H. Brimhall, D. Nahon, C.J. Lewis, A. Baronnet, and K. Danty, "Equatorial rainforest lateritic mantles: a geomembrane filter", Geology, vol. 20, pp. 523-526, 1992.

[22] L.R. Garner, "Mobilization of $\mathrm{Al}$ and $\mathrm{Ti}$ during weathering isovolumetric geochemical evidence", Chem. Geol., vol. 30, pp. 151-165, 1980.

[23] B. Boulangé, "Bauxitic formations of Ivory Cost. Facies, their transformation, their distribution and relief evolution", thèse d'Etat, Université de Paris VII, Paris, France, 1983.

[24] E. Temgoua, "Actual ferruginous accumulations of footslope in south Cameroon rainforest zone. Petrological evolutions of facies and trace elements in relation with the duricrusting", thèse Doct., Université de Lausanne, Lausanne, Suisse, 2001.

[25] S. Gaviria, "Mineralogical and geochemical evolution of iron and aluminium in hydromorphic ferrallitic soils of eastern Llanos of Colombia. Early stage of duricrusting", thèse Doct., Université de Nancy I, Nancy, France, 1993.

[26] E. Jeanroy, "Diagnostic of iron forms in temperate pedogenesis. Evaluation by chemical extractant reagents and contribution of Mössbauer spectrometry", thèse Doct., Université de Nancy I, Nancy, France, 1983.

[27] E. Jeanroy, J.L. Rajot, P. Pillon, and A.J. Herbillon, "Differential dissolution of hematite and goethite by dithionite and its implication on soil yellowing", Geoderma, vol. 50, pp.79-94, 1991.

[28] S. Bravard, "Podzolisation in brasilian amazonia. Study of ferrallitic soil-podzol sequence of the northern Manaus region", thèse Doct., Université de Poitiers, Poitiers, France, 1988.

[29] C. Boupassia, "Study of soils and mining residue of Moanda region in the south east of Gabon: rehabilitation perspectives of the Bangombé manganiferous plateau", thèse Doct., Université de Bourgogne, Dijon, France, 2004. 
[30] G. Lévy, and F. Toutain, "Weathering and oxydo-reduction phenomenon in soil", in Pedology Tome II. Soil constituents and properties, $2^{\text {nd }}$ ed., M. Bonneau, B. Souchier, Eds., Paris, Masson, 1994, pp. 467-478.

[31] Ph. Duchaufour, Ed., Masson, Paris, 1977.

[32] G. Pédro, "Geochemical characterisation attempt of the different zonal processes resulting from superficial weathering", C.R. Acad. Sci., vol. 262, pp. 1828-1831, 1966.

[33] M.F. Hossain, "Arsenic contamination in Bangladesh. An overview", Agric. Ecosyst. Environ., vol. 113, pp. 1-16, 2006.

[34] A. Joubert, "Study of environmental factors effect on biogeochemical processes of $\mathrm{Pb}, \mathrm{Zn}, \mathrm{Cd}$, As and $\mathrm{Hg}$ mobilization in soils. Empirical modelling of the ETM mobility and phytoavailability", thèse Doct., Université Henri Poincaré-Nancy I, Nancy, France, 2008.

[35] P. Ségalen, Ed, ORSTOM, Paris, 1964.

[36] P. Ségalen, Ed, ORSTOM, Paris, 1973.

[37] P. Quantin, "Andosols (= andic soils)", in French Pedologic Referential, AFES, INRA, $3^{\text {ème }}$ proposition, 1990, pp. 77-78.

[38] J.P. Boudot, B.A. Bel Hadj, and T. Chone, "Carbon mineralization in andosols and aluminium rich highland soils", Soil. Biol. Biochem, vol. 18, pp. 457-461, 1986.

[39] J.P. Boudot, B.A. Bel Hadj, and T. Chone, "Dependence of carbon and nitrogen mineralization rates upon amorphous metallic constituents and allophanes in Highland soils", Geoderma, vol. 42, pp. 245-260, 1988.

[40] J.P. Boudot, B.A. Bel Hadj, and R. Steiman, "Biodegradation of synthetic organo-metallic complexes of iron and aluminium with selected metal to carbon ratios", Soil. Biol. Biochem, vol. 21, pp. 961-966, 1989.
[41] K. Inoue, and T. Higashi, "Al- and Fe-Humus complexes in Andisols", in Proceedings of the Ninth International Soil Classification Workshop, D.L. Kinloch, S. Shoji, F.H. Beinroth, and H. Eswaran, Eds., Washington D.C., USA, Japanese Committee for the Ninth International Soil Classification Workshop for the Soil Management Support Services, 1988, pp. 81-96.

[42] J.P. Boudot, "Relative efficiency of complexed aluminium, noncrystalline $\mathrm{Al}$ hydroxide, allophane and imogolite in retarding the biodegradation of citric acid", Geoderma, vol. 52, pp. 29-39, 1992.

[43] R. Dahlgren, S. Shoji, and M. Nanzyo, "Mineralogical characteristics of volcanic ash soils", in Volcanic Ash SoilsGenesis, Properties and Utilization, S. Shoji, M. Nanzyo, and R.A. Dahlgren, Eds., Developments in Soil Science, Elsevier, vol. 2, 1993, pp. 101-143.

[44] B. Guillet, "Ageing of organic matter and organo-mineral associations of andosols and podzols", Science du Sol, vol. 28, pp. 285-299, 1990.

[45] B. Guillet, "Natural carbon isotopic abundance as a study method of dating, renewal and of the origin of soil organic matter", in Pedology Tome II. Soil constituents and properties, $2^{\text {nd }}$ ed, M. Bonneau, B. Souchier, Eds., Paris, Masson, 1994, pp. 297-315.

[46] M. Nanzyo, R. Dahlgren, and S. Shoji, "Chemical characteristics of volcanic ash soils", in Volcanic Ash Soils-Genesis, Properties and Utilization, S. Shoji, M. Nanzyo, and R.A. Dahlgren, Eds., Developments in Soil Science, Elsevier, vol. 21, 1993a, pp. 145187.

[47] AFES, Pedologic Referential, INRA, Paris, 1995.

This is an open access article licensed under the terms of the Creative Commons Attribution Non-Commercial License (http: //creativecommons.org/licenses/by-nc/ $3.0 /$ ) which permits unrestricted, non-commercial use, distribution and reproduction in any medium, provided the work is properly cited 